\title{
Do Locals Rule? Interactions between Native Intertidal Animals and a Caribbean Barnacle in Hawai' $i^{1}$
}

\author{
Chela Zabin and Micbael G. Hadfield ${ }^{2}$
}

Cbthamalus proteus, a high intertidal barnacle from the Gulf of Mexico and the Caribbean, is one of the most conspicuous recent introductions to Hawaiian waters. It arrived sometime between the early 1970s, when the last thorough survey of intertidal barnacles on O'ahu was done (Matsuda 1973), and the late 1990s, when it was photographed by an amateur biologist who was putting together a book on Hawai'i's sea creatures (Southward et al. 1998). On O'ahu, the barnacle attains high densities in protected bays and lagoons, particularly where there are few other intertidal organisms. Cbthamalus proteus is somewhat less abundant in semiprotected waters where it co-occurs with a suite of native organisms. We examined interactions between $C$. proteus and two native Hawaiian species, the barnacle Nesochthamalus intertextus and the pulmonate limpet Siphonaria normalis.

The native barnacle is highly abundant on seawalls in Waikīī and frequently overgrows or undercuts the invader. Nesocbthamalus intertextus grows twice as fast as C. proteus, which may allow the native to compete more effectively for space. To examine whether the native barnacle is limiting the distribution of the invader, we established 20 permanent quadrats along a seawall. In half of the quadrats native barnacles within $5 \mathrm{~mm}$ of invasive barnacles were removed; the remaining quadrats served as controls. Growth and survivorship of invasive barnacles in the quadrats have been tracked for $1 \mathrm{yr}$. An additional 12 quadrats

\footnotetext{
${ }^{1}$ Extended abstract of paper presented at the Ninth International Coral Reef Symposium, Bali, Indonesia, 27 October 2000. Manuscript accepted 5 September 2001.

2 Zoology Department, Kewalo Marine Laboratory, University of Hawai $i$, Honolulu, Hawai' $i$.
}

Pacific Science (2002), vol. 56, no. 2:235-236

(C) 2002 by University of Hawai'i Press.

All rights reserved were cleared of all native intertidal organisms. Recruitment of $C$. proteus to these quadrats and to 12 control quadrats was recorded for 10 months. Invasive barnacles in the treatment quadrats grew faster than those in control plots. Neither recruitment nor mortality was significantly different in treatment versus control plots, however, suggesting that factors other than competition (such as larval supply) also play a role in the distribution of the invader.

It is more usual to ask whether an invader is impacting a native. There were too few of the invasive barnacles at Waikiki to test this with any statistical power. At Kualoa Beach, on O'ahu's windward side, the situation is reversed: the invader is abundant and the native is relatively rare. An experiment similar to the one in Waikiki was established in March 2000 to test the effect of C. proteus on the growth, mortality, and recruitment of $N$. intertextus. After $1 \mathrm{yr}$, there appeared to be no effect of the invader on the native in any of these categories.

Interactions in Kāne'ohe Bay between $C$. proteus and the pulmonate limpet $S$. normalis were also examined. The pulmonates are highly abundant (mean $30 / 100 \mathrm{~cm}^{2}$ ) at Coconut Island on a seawall that is composed of several rock types. A survey of the wall showed that the invasive barnacles were less abundant on light-colored rock and that there was an additional negative effect of pulmonate density on barnacle abundance. The pulmonates were more abundant on light-colored rock; their densities were not additionally affected by barnacle numbers. Four types of cement settlement panels (dark smooth, dark rough, light smooth, light rough) were placed in the intertidal to test for settlement preferences of $C$. proteus and $S$. normalis. Barnacles did not show a preference for color, but limpets recruited preferentially to light-colored panels. Further experiments examining the effect of the pulmonates on recruitment of $C$. 
proteus and the effect of barnacles on homescar choice for juvenile and adult $S$. normalis are in progress.

\section{Literature Cited}

Matsuda, C. 1973. A shoreline survey of freeliving intertidal barnacles (Class Crustacea, Subclass Cirripedia; Order Thoracia) on the island of Oahu, Hawaii. M.S. thesis, University of Hawai'i at Mānoa, Honolulu.

Southward, A. J., R. S. Burton, S. L. Coles, P. R. Dando, R. DeFelice, J. Hoover, P. E. Parnell, T. Yamaguchi, and W. A. Newman. 1998. Invasion of Hawaiian shores by an Atlantic barnacle. Mar. Ecol. Prog. Ser. 165:119-126. 